\title{
Editorial Statement for MOR Dialogue, Debate, and Discussion
}

\section{Liisa Välikangas}

Aalto University and Hanken School of Economics, Finland (liisa.valikangas@aalto.fi)

\section{WELGOME TO MOR DIALOGUE, DEBATE, AND DISCUSSION}

I am honored to join the MOR editorial team as the editor for Dialogue, Debate, and Discussion. My commitment is to facilitate dialogue, debate, and discussion on management and organization theory that is rooted in practice in emerging economies yet has implications beyond. Let us learn 'slowly' (cf. Levinthal \& March, 1993) and resist too fast convergence to Western management methods before we have a chance to better understand and assimilate the divergence around the world.

This may be a unique time for studying management laboratories - not only geographically in emerging economies but also in terms of global opportunities powered by digital technologies and enabled by increasing mobility of people and accessibility of finances. I join Gerard George in his Editorial (this issue) in the call for rejuvenating management ideas and nuancing them with practice. A recent article in The Economist discusses the splintering of work into on-demand performance ('Workers on Tap', The Economist, January 3, 2015). Opportunities and their organizing may be becoming more liquid than ever (Bauman, 2000).

Challenges to orthodoxy? Simon Liang from Evergreen conglomerate, in a recent management conference, replied to a Rumelt afficionado that unrelated diversification, far from being inefficient, was rather 'natural'. When opportunities are abundant, it may pay to explore broadly; or, using the Google bent, it is much better to fail and learn than miss an opportunity. Our understanding of innovation might benefit from studying such management practices that perhaps downplay refining exploitation practices above exploration (March, 1991) or that do not undermine the institutions that support the very innovating (Schumpeter, 1942/1950). Perhaps emergent economies offer a window on the development of the world where wealth concentration has severe implications, again.

Emerging economies could transform our views of management if we so allow. I am fond of a story of a South African who returned to his dwelling after a workday, washed his shovel, and used it as a frying pan. That is cognitive malleability of the 
kind maybe needed to rethink organization and management theory. Such resource scarcity has already fueled new thinking (e.g., Prahalad, 2004) and inspired 'reverse innovation' (Govindarajan \& Trimble, 2012). It is likely that companies in emerging economies are malleable and scarce in ways not yet included in our theorizing while experimenting on different management principles beyond the industrial legacy we have inherited.

This column is reserved for debate and discourse on generative new thinking. Being generative, at its heart, means the following: We may be wrong but at least let us be wrong in such a way that it inspires new ideas and passionate discussion (e.g., Carlsen \& Dutton, 2011). Humor plays an important part (Otto, 2001). When did you last laugh when reading of management and organization? Lucy Kellaway from Financial Times acts as an official jester of corporate practice by making fun of obscure and stale notions. Perhaps there is also the joy of laughter that opens up serendipitous learning following Weick's (1989) notion of 'that's interesting'. Serendipity (Merton \& Barber, 2003) may be one avenue for learning from outliers, organizations that are so different as to be suspected of having been created by a different mechanism (Hawkins, 1980) and, hence, usually rejected as error or noise. Rather than rejecting the different, should it not be the target of our intellectual curiosity? Is being different not the core of strategic management? Outliers may be a first key to new theorizing, indeed manifestations of a different mechanism of addressing institutional conditions, decomposition of work, or managers' personal understandings of management efficacy (Lewin, 2014).

There is a laboratory of management and organization in emerging economies that this journal has a proud history of reporting. This column seeks to build on and expand - and challenge - that history.

Dialogue, Debate, and Discussion submissions are open.

EDITORIAL AREA KEYWORDS Challenge orthodoxy; emerging economies transforming views of management; debates and discourses on resilient or generative new thinking; draw on humor, or even irony, to shut down or engage important neglected management realities; invitations to transformative dialogues on theory and practice

\section{REFERENGES}

Bauman, Z. 2000. Liquid modernity. Cambridge: Polity.

Carlsen, A., \& Dutton, J. 2011. Research alive: Exploring generative moments in doing qualitative research. Copenhagen: Copenhagen Business School Press.

Govindarajan, V., \& Trimble, G. 2012. Reverse innovation: Create far from home, zin everywhere. Cambridge, MA: Harvard Business School Press.

Hawkins, D. M. 1980. Identification of outliers. London: Chapman and Hall.

Levinthal, D., \& March, J. G. 1993. The myopia of learning. Strategic Management Journal, 14(S2): 95-112.

Lewin, A. 2014. Emerging economies open unlimited opportunities for advancing management and organization scholarship. Management and Organization Revieze, 10(1):1-5. 
March, J. G. 1991. Exploration and exploitation in organizational learning. Organization Science, 2(1): 71-87.

Merton, R., \& Barber, E. 2003. The travels and adventures of serendipity: A study in sociological semantics and the sociology of science. Princeton, NJ: Princeton University Press.

Otto, B. 2001. Fools are everyzhere: The court jester around the world. Chicago, IL: University of Chicago Press.

Prahalad, G. K. 2004. The fortune at the bottom of the pyramid: Eradicating poverty through profits. Upper Saddle River: Wharton School Publishing.

Schumpeter, J. 1942/1950. Capitalism, socialism and democracy. 3rd ed. New York: Harper and Brothers.

Weick, K. 1989. Theory construction as disciplined imagination. Academy of Management Revieze, 14(4): 516-531. 